\title{
BUILDING THE EMPIRE STATE
}




\title{
AMERICAN BUSINESS, POLITICS, AND SOCIETY
}

\author{
Series editors: \\ Andrew Wender Cohen, Pamela Walker Laird, \\ Mark H. Rose, and Elizabeth Tandy Shermer
}

Books in the series American Business, Politics, and Society explore the relationships over time between governmental institutions and the creation and performance of markets, firms, and industries large and small. The central theme of this series is that politics, law, and public policy-understood broadly to embrace not only lawmaking but also the structuring presence of governmental institutions-have been fundamental to the evolution of American business from the colonial era to the present. The series aims to explore, in particular, developments that have enduring consequences. 


\title{
BUILDING THE EMPIRE STATE
}

Political Economy in the Early Republic

\section{Brian Phillips Murphy}

\author{
$\overline{\text { PENN }}$ \\ UNIVERSITY OF PENNSYLVANIA PRESS \\ PHILA DELPHIA
}


Copyright $(92015$ University of Pennsylvania Press

All rights reserved. Except for brief quotations used for purposes of review or scholarly citation, none of this book may be reproduced in any form by any means without written permission from the publisher.

\author{
Published by \\ University of Pennsylvania Press \\ Philadelphia, Pennsylvania 19104-4112 \\ www.upenn.edu/pennpress \\ Printed in the United States of America \\ on acid-free paper
}

13579108642

\title{
Library of Congress Cataloging-in-Publication Data
} Murphy, Brian Phillips.

Building the empire state : political economy in the early republic / Brian Phillips Murphy.

pages $\mathrm{cm}-$ (American business, politics, and society)

Includes bibliographical references and index.

ISBN 978-0-8122-4716-9

1. New York (State)-History-1775-1865. 2. New York (State)Politics and government-1775-1865. 3. New York (State)Economic conditions-History-18th century. 4. New York (State)-Economic conditions-History-19th century. 5. Finance, Public-United States-New York (State)-1789-1801. 6. Finance, Public-United States-New York (State)-1801-1861. I. Title. II. Series: American business, politics, and society.

F123.M93 2015

974.7'03-dc23 
For my father, James J. Murphy III

(1943-2013) 
This page intentionally left blank 